University of Nebraska - Lincoln

DigitalCommons@University of Nebraska - Lincoln

Faculty Publications: Department of Teaching, Department of Teaching, Learning and Teacher Learning and Teacher Education

Education

2013

\title{
A Case Study of Reading Instruction in a Philippine Classroom
}

Maria Selena Protacio

Western Michigan University, selena.protacio@wmich.edu

Loukia K. Sarroub

University of Nebraska-Lincoln, Isarroub@unl.edu

Follow this and additional works at: https://digitalcommons.unl.edu/teachlearnfacpub

Protacio, Maria Selena and Sarroub, Loukia K., "A Case Study of Reading Instruction in a Philippine Classroom" (2013). Faculty Publications: Department of Teaching, Learning and Teacher Education. 132. https://digitalcommons.unl.edu/teachlearnfacpub/132

This Article is brought to you for free and open access by the Department of Teaching, Learning and Teacher Education at DigitalCommons@University of Nebraska - Lincoln. It has been accepted for inclusion in Faculty Publications: Department of Teaching, Learning and Teacher Education by an authorized administrator of DigitalCommons@University of Nebraska - Lincoln. 


\title{
A Case Study of Reading Instruction in a Philippine Classroom
}

\author{
Maria Selena Protacio \\ Department of Special Education and Literacy Studies, Western Michigan University, Kalamazoo, MI, USA. \\ Corresponding author - email selena.protacio@wmich.edu
}

\section{Loukia K. Sarroub}

Department of Teaching, Learning, and Teacher Education, University of Nebraska-Lincoln, Lincoln, NE, USA

\begin{abstract}
In this article, we describe the reading practices in a public and high-achieving 6th grade English classroom in the Philippines. By utilizing a four resources model, we discuss the different roles that students assume in this classroom. Students in this class are mainly code breakers and text users and have limited opportunities to assume the other two roles of the four resources model. This case study provides a different view of reading, specifically a view of a culture of reading wherein higher status is given to oral reading performance rather than comprehension. We describe the way a high-achieving 6th grade Philippine classroom perceives reading. Through this article, we would like to contribute to the research literature on Philippine education and increase our knowledge of reading practices as they are conceived and practiced in this particular classroom.
\end{abstract}

Keywords: reading instruction, Philippine education

\section{Setting and context of the study}

As authors of this article, we represent both a local and international collaboration. Selena, a Filipina and a former English teacher in the Philippines, wanted to explore what reading looked like in an elementary school setting. Loukia, the second author of this article, worked closely with Selena during the research and writing process of this ethnographic case study. Loukia's expertise in literacy and cross-cultural studies as well as ethnographic research methods offered a complementary perspective to Selena's knowledge about and experiences in the Philippines. We wanted to learn more about classroom life in a country with which we are familiar and unfamiliar.

For this study, we decided to focus on the 6th grade since Philippine national assessments are conducted at this level; thus, it seemed extremely relevant to examine reading practices at this grade. Once Selena gained access to a particular school, the principal assigned her to observe in the highest achieving 6th grade classroom (referred to within the school as the "pilot section"). In Philippine public schools, there is a hierarchy of classroom sections based on academic achievement. It could be perceived as a continuum of the successful students to the "successful failures" in the school system (Varenne \& McDermott, 1998). Because of the stringent admission procedures, the students in the pilot section are consequently perceived to be the best in their respective grade levels. They have been constantly sifted throughout their primary grades to ensure they are capable of becoming high achievers. 
The hierarchy of the sections in this school could be interpreted as the school's conforming to the social efficiency perspective (Labaree, 1997), wherein students are prepared for their expected roles in society. Students are placed in sections according to their academic achievement, and one's placement in a section is indicative of his or her grades. For the 6th grade, there are seven sections. In other words, those who are in the pilot section are the academic achievers in that grade level while students in Section 7 are perceived to be the lowest achievers.

\section{Research question}

As we learned more about this classroom life, we asked the following question: How is reading perceived in this classroom?

\section{Theoretical perspective}

For this study, we utilize Freebody and Luke's (1990) four resources model, wherein they posit that to be a successful reader in a society, an individual usually enacts and sustains four roles or family of practices (Luke \& Freebody, 1999): code breaker, text participant, text user, and text analyst. While we discuss the four roles individually below, we want to emphasize that readers do not assume one role at a time in a developmental fashion. While reading texts, good readers simultaneously assume more than one of these roles as part of the reading process and engage with texts aesthetically even as they also decode or read them critically.

First, code breaker deals with readers being able to decode words and understand how texts work (e.g., understanding sound-letter relationships). Freebody and Luke emphasize that even though being a code breaker is an essential component of literacy, additional literacy skills and practices needed. An autonomous view of literacy, as Street (2005) points out, limits reading to a set of skills, and that is not an accurate portrayal of what kids actually do when they read. The second role in the four resources model is that of the text participant wherein the reader addresses the meaning system of the text. With this role, individuals draw inferences and understand textual elements. In addition, Freebody and Luke specify that for English Language Learners (ELLs), background knowledge is essential in order to be a text participant. ELLs bring "varying bodies of cultural knowledge and competence to bear on the text" (Freebody \& Luke, 1990, p. 10). Thus, the authors emphasize a need for guided and explicit instruction when there are texts that make meaning demands on students. Text user is the third role in this model wherein individuals participate in reading and writing as social experiences. It is through sociocultural experiences that individuals conceptualize what to do with texts. The last role is that of a text analyst wherein readers understand that texts are not neutral objects; rather, the authors of texts are people who have their own orientations and dispositions toward the world and share those with readers. It is the text analyst's role to be a critical reader of texts and to question the author(s). Through the four resources model, Freebody and Luke suggest that literacy is multifaceted. They do not privilege one reader role over the others. Rather, they posit that each role is relevant to the other for one to be an effective reader and that readers draw on all four resources to make sense of texts.

\section{Research methodology}

\section{Data collection}

An ethnographic case study approach was used for this study. Fieldwork was conducted in the 6th grade pilot section in a public school in Laguna, a province 54 miles south of 
Metro Manila. The town in which the school is located is an urban municipality with a population of approximately 82,000 , and its population is a mix of upper middle class to working class families.

Classroom observations began during the second week of June 2006, shortly after the beginning of the new academic year (the typical Philippine school year runs from June to March). Selena observed the class for eight weeks with a total of 21 classroom observations, each of which lasted 60-75 minutes. Selena's main role in the classroom was an observer. However, Mrs. Mendoza (all participant names are pseudonyms) enlisted Selena's help to conduct a diagnostic reading assessment to the students in two of the observations. These were the only times that Selena participated in class activities as a participant-observer. Descriptive field notes were written for all the sessions observed (Bogdan \& Biklen, 2003; Emerson, Fretz, \& Shaw, 1995) and were read and reviewed by Loukia.

Semi-structured interviews were conducted with the classroom teacher, six focal students, and the head teacher of the school, the equivalent of the assistant principal in US schools. Three interviews were conducted with the classroom teacher while two interviews were held with five of the focal students. One student was sick during the week of the second interviews, and thus she was interviewed only once. The head teacher was also interviewed once to obtain more background information about the school.

\section{Participants}

Mrs. Mendoza served as the primary participant of this study as she was the adviser and English teacher of the pilot section. Mrs. Mendoza initially taught in a private school for 5 years, but she transferred to the public school system and had been teaching in Garcia Elementary School for 16 years. This was Mrs. Mendoza's second year as the adviser of the 6th grade pilot section. In the Philippines, beginning in elementary schools, different subjects are taught by different teachers, similar to the subject specialization that occurs in US high schools. Thus, since students have different teachers for the content areas, each class is assigned an adviser who will take care of all matters not covered by the different subject matter teachers. Such tasks include preparing the report cards of the students in the section as well as overseeing and ensuring the cleanliness of the classroom environment. Mrs. Mendoza also taught the 4th grade pilot section in the past and has had experience in teaching high achieving students. Mrs. Mendoza's varied experiences provide her with different perspectives from which she views reading instruction in the Philippines.

The pilot section was composed of 45 students, with 30 girls and 15 boys. Mrs. Mendoza said 50 slots were allotted for the pilot section, but no other students qualified for admission to the class so this class was actually smaller than usual. At the beginning of the study, consent forms were given to the students and parents of whom approximately one third did not consent. Among the remaining students, six focal students were chosen after four weeks of observation. These students were chosen based on their academic performance as well as Mrs. Mendoza's recommendation. We purposely selected two each of high, average, and low achievers once initial observations showed that even though the pilot section was supposedly a homogenous group of high achievers, there was still a spectrum of reading skills exhibited by the students.

Student participants included Miguel, one of the high achieving students in the class who obtained the second highest grade point average at the end of 5th grade. Mrs. Mendoza described him as one of the leaders of the class. He was one of the few students who elaborated on his answers during recitation. Miguel enjoyed reading informational texts such as the atlas, and during our interviews, he even mentioned trivia he learned from read- 
ing. Michelle was the other high achieving focal student. Mrs. Mendoza described her as a good student who kept to herself. During our interviews, Michelle mentioned the support both her parents give to her studies. Michelle also mentioned that her parents encouraged her to focus on the grammar instead of reading literature because they thought her grammar skills were less developed.

Richard and Angel were average achieving students. Richard was one of the students that Selena immediately noticed because Mrs. Mendoza called on him frequently to read aloud. During the interviews, Richard immediately expressed his enthusiasm for learning new vocabulary words, and he shared that he actively read the dictionary so he could learn new English words. In addition, Richard said that he read the dictionary so that when he was called on to read in class, he would know how to pronounce a word. The other average achiever, Angel, was one of three new students in the pilot section who transferred from another school. She was a soft-spoken girl who managed to adapt to the classroom culture. However, she noted that the hardest adjustment had been the teasing by her classmates. She said that teasing was not something she was accustomed to but everyone teased and got teased in the pilot section.

Tony and Jayca were the lower achieving focal students. Tony was new to the pilot section as he transferred from section 5 after passing the qualifying exam. Tony admitted that he found his new class challenging because many of the students "[were] smart." Tony also discussed his lack of support in his new classroom compared to his previous one. He explained three of his cousins were his classmates in section 5, and they frequently encouraged him to do well. However, he only has one cousin in the pilot section, who did not offer the same level of moral support. Meanwhile, Jayca was a very quiet student. During our interviews, she was very hesitant to speak and did not elaborate her answers. When called on during class recitation, Jayca would frequently take a long time to answer, usually glancing at her classmates for confirmation of the right answer, or sometimes, she would not answer at all.

Thus, even though this was supposedly a high achieving classroom with the best students of the entire grade level, there was still a continuum of skill and self-efficacy with regard to students' reading abilities. The variation in the focal students provided different lenses from which we could analyze the reading practices in the classroom.

\section{Data analysis}

The field notes and interview transcripts were analyzed and coded based on recurring themes, patterns, and ideas. Open and focused codes were applied to the field notes (Emerson, Fretz, \& Shaw, 1995). Examples of open codes were reading aloud, student response, and spelling drills. Triangulation of codes and themes was applied across interview transcripts, field notes and various classroom and school artifacts. As we noticed patterns, we collapsed some open codes into focused codes. For example, reading as performance, the main theme of this article, emerged from open codes such as reading aloud, pronunciation drills, and pronunciation emphasis.

Selena took the lead in coding the field notes, developing a list of 891 open codes after we reviewed the field notes together. We met weekly for a year as we reviewed the codes, connected them back to the field notes, questioned their relation to classroom interaction, and collapsed them into emerging themes after clarifying their reliability in establishing patterns that defined the classroom culture and reading practices.

Selena wrote analytical memos that were reviewed by Loukia, and the functions of these memos were twofold: (a) they related the data to the formulation of theory, and (b) they helped us gain analytical distance from the field itself (Miles \& Huberman, 1994; Strauss \& 
Corbin, 1990). In addition, a comparative and ethnographic analysis of the interviews was utilized, and this included audio taping, transcription, and coding. Domain analysis was carried out for the interviews (Spradley, 1979) and triangulated with the observation codes.

\section{Findings}

According to Mrs. Mendoza, all the students in the pilot section were able readers; they did not have problems with decoding, indicating that students in the pilot section were comfortable as code breakers, processing text automatically and being skilled at reading. Mrs. Mendoza also said that most of the students were able to comprehend what they are reading. Mrs. Mendoza admitted there are some students, such as Jayca, in the pilot section who struggle with comprehension, but most of the students could "comprehend fairly well." Thus, within the four resources model, students were also text participants, but as we analyzed our field notes, we found that comprehension was not much of a focus in this classroom. Rather, our analysis suggests a prominent theme, that reading was perceived as a performance. The role that seems to be especially salient in this classroom is that of a text user, which indicates that reading and writing have a contextual component. Indeed, in this class, being a good reader was not about decoding or comprehension. Rather, the focus was more about becoming a fluent reader, one who is able to read accurately and with proper pronunciation and expression.

Philippine literacy scholars have commented on the emphasis on performance and reading aloud. Maminta (1982) discusses how reading as a subject was relegated to the background as the curriculum emphasized speech improvement with most of the class time being spent on pattern drills, mimicry, and memorization. Even though Maminta's article focuses on speech improvement as being the emphasis three decades ago, it seems that it still characterizes classroom practice in the Philippines today. In the pilot section, the students themselves seemed to be the ones placing the emphasis on speech improvement. In fact, the students were quite aware of their status as good articulators of English, and some wanted to read texts aloud. There were also instances during which the teacher also emphasized pronunciation and enunciation. Other times, oral reading performance was emphasized because there were not enough books for each child in this and other public schools (as Mrs. Mendoza remarked to Selena) and reading aloud gave each student access to print literacy.

During the first observation, the teacher called on Richard, a focal student. The field note excerpt illustrates that Richard read well, but as he read for 10 consecutive minutes, he committed more and more reading miscues.

Mrs. Mendoza hands the book over to Richard, who sits in the third row. Richard says the title of the story:

"A Reason for Everything," in a clear, loud voice. He reads the story of Tata Karyo, whose barrio (small village in the province) was hit by a strong typhoon. His crops were destroyed, but Tata Karyo saved what crops he could. He also did not dwell on his misfortunes as some other people may have done. Richard is a fluent reader, and he changes his facial expressions while he reads. During one part of the story, though, Richard pronounces the word as ah-terred and Mrs. M corrects him and says it is uttered. Richard goes on to read the story, but a couple of paragraphs later he says lounge shed and Mrs. Mendoza corrects him, saying it is pronounced as languished. Richard commits more miscues towards the end of the story. By this time he had been reading for 10 straight minutes. 
Despite the reading miscues that he made as noted in the vignette, Richard is one of the more fluent readers in the classroom. During the first interview, Richard shared that he had been called on to read in front of the class since the first grade. Richard said that he is happy when he is called to read because "I like it that they are able to hear my voice, which is loud and my pronunciation of English words is okay." He later commented, "I understand it [the story] better when I'm the one reading because I can see the pictures and words for myself. Because sometimes when someone else is reading, the words are not pronounced correctly." Richard's comment underscores the importance of access to text. As Richard noted, his comprehension was better when he read the text himself, even if he had to read it aloud to his peers. He was able to see the words and associated pictures with the texts, while other students needed to rely on him to articulately read the text so they could also comprehend it. In essence, Richard's reading comprehension and fluency were targeted while for other students, they were only able to hone listening comprehension skills.

In the above example, Richard also highlighted the importance of correct pronunciation, which was a topic that several of the focal students raised. Pronunciation drills were conducted six times during the 21 observations. There were drills of isolated words as well as ones in which the teacher proceeded from isolated words to phrases and then to complete sentences. For pronunciation lessons, Mrs. Mendoza typically posted a manila paper in which the words, phrases, and sentences were written. The teacher read the words, and the students repeated them. In other instances, after the class read the words together, the teacher called on different rows of students to read them. After these small groups read the words, the teacher then called on individuals to read the words, phrases, and sentences aloud. If there were instances during which the students mispronounced words, the teacher was quick to correct the pronunciation of these individual students.

The topic of correct pronunciation seemed to be a source of anxiety for some students in the classroom. A key example of this was Michelle. She was one of the higher performing students in the class, but she was not called on as often as Miguel or Richard to read aloud to the class. The following is an excerpt of her first interview in which she explains her perceptions of herself as a reader.

Selena: Well what do you think are things you have to work on as a reader?

Michelle: Pronunciation. So that they can understand me, I need to read it fast. It's like when I see a short word in the book, I have a problem with the pronunciation.

Selena: I've seen you read in front of the class a couple of times. Are you confident when you read out loud to your classmates?

Michelle: I'm used to it but when it's stuff onstage, I get nervous, of course.

Selena: What do you do or you and your mom do so you can fix what is lacking in your pronunciation?

Michelle: What Ma'am Mendoza taught us, the breathing exercises. Mommy encourages me to do that.

Selena: So you do it. When do you do this?

Michelle: Every Saturday and Sunday before I go to sleep. Just so that my voice will be relaxed.

In her interview, Michelle focused on the oral aspect of reading. At home she did breathing exercises so that she would perform better at school as an oral reader. Interestingly, Michelle did not mention being anxious about her comprehension skills as a reader, and she instead focused her response on reading aloud.

Angel had a related response when asked about her thoughts on reading aloud in class, "I don't know. I feel embarrassed because maybe my pronunciation is wrong or something 
like that." These examples indicate that focal students, even the high achieving student, were concerned with correctly pronouncing words when they were asked to read aloud to the class. Tony and Jayca, however, did not mention these concerns about pronunciation and perhaps it is because they are not asked to read texts aloud to the entire class.

Kim and Krashen (1997) found that adult acquirers of English were reluctant to use reading as means to improve their speaking abilities. These non-native English speakers said they had studied English in their home country, Korea, but the emphasis was on grammar rules and drills; thus, they were insecure about using English because they felt they were not competent in speaking the language.

Similar to these findings, we found that in the interviews with Mrs. Mendoza and the focal students there was some hesitancy and even some resistance to conducting the interviews in English. Being bilingual in English and Filipino, Selena could conduct the interview in either language. In some interviews, she initially spoke in Taglish (a combination of Tagalog and English), so the student could choose in which language s/he would reply. Out of the six focal students, four chose to respond in Filipino. Two of the students, Miguel and Tony were interviewed together. Tony, one of the lower achieving students in the class as well as one of the new students in the section, asked Selena if it was possible for him to join Miguel's interview. During the interview Miguel was the first one to answer, and he replied in English. When it was Tony's turn to reply, he also replied in English. It was interesting that these two students, one a high achiever and one a low achiever, could both communicate fairly well in their second language despite the disparity in their reading performance and status in the class.

Miguel talked in English during the entire interview. He sometimes struggled to think of the right words, and there were grammatical lapses in some of his sentences. Tony sometimes injected the Filipino word ano, which literally means what. Its connotative meaning is the rough equivalent of like, as it is a filler word that many people inject when they are thinking about what to say next. In this excerpt from the interviews, Selena asked the students to describe what they usually do in English class.

Selena: What are the usual topics that are covered by the activity sheets?

Miguel: The usual topics covered by the activity sheets are getting the main idea, supporting details, sequencing and so on.

Selena: Tony, what else can you add? What do you usually do during these activities?

Tony: We're writing in the manila paper and some questions in the old folders are, ano (what), are, like, make, there are, there are story in the board and we will write the main idea and supporting details in the manila paper and, and we will report about it.

From this excerpt, we can see that Tony was able to keep up with Miguel in English. Despite being one of the lower achieving students in the class, Tony was able to successfully communicate in English, meeting the Philippine Department of Education's goal of functional literacy for all students. However, it is interesting to note that out of the 21 observations that Selena conducted, Tony and any other of the lower achieving students in the pilot section, were not asked to read aloud to the class. Thus, if reading in this class is synonymous to reading aloud, what are the perceptions of these lower achieving students of their reading capabilities if they are not given opportunities to practice their oral reading skills? How can they assume the role of a text user when they are not afforded an opportunity to "perform" in front of the class as an oral reader? The lower achieving students are deprived of the chance to fully become a member of the reading community in the class since they are not chosen to read aloud. 
On the other hand, Miguel was one of the students who first caught Selena's attention because he was frequently called on to read aloud and to respond during class recitation. When Selena assessed Miguel on the diagnostic test, which was an oral reading assessment, he started reading the passages with a British accent. The following day, during the second part of the diagnostic test wherein the students had to read words in isolation, Miguel read with standard Philippine English pronunciation.

The following is an excerpt from the second interview with Miguel. Selena asked him about the British accent she noted during the diagnostic test, and Miguel explained that he has been practicing "speaking other sounds."

Selena: I remember in the first couple of sessions, during the reading inventory, I think, and you were reading to me outside, you were speaking with a British accent. What can you say about that? I thought you were a foreigner.

Miguel: Because I'm just practicing for speaking, speaking other sounds.

Selena: So you were just practicing. How do you get those accents?

Miguel: I get those accents when I was, when I was reading the dictionary.

Selena: How do you get it from reading the dictionary?

Miguel: Because the accent is, are on the dictionary and their etymology are also in the dictionary.

The "other sounds" to which Miguel referred pertain to the phonetic spellings of a word. Lu (2002) discusses the difficulty that Cantonese speakers have in Hong Kong with phonetic symbols because reading these is not a part of their curriculum. Thus, these learners have trouble with English pronunciation because of a lack of knowledge of English sounds. On the other hand, the students in the pilot section were regularly exposed to phonetic symbols. Every Monday, the teacher provided the students with 10 spelling words. Their assignment for the next day was to find the meaning, syllabication, phonetic spelling, and the parts of speech these words represented. Thus, students were accustomed to consulting the dictionary for the phonetic spelling of different words. Furthermore, some students, including Miguel and Richard, actively studied the dictionary to improve their pronunciation of English in order to give a good oral performance. In an interview, Richard noted, "When I see the phonetic spelling, I then know how to pronounce it." He elaborated that studying the phonetic spelling of words is another reason why he actively studied the dictionary, especially since this helps him figure out the pronunciation of words as he is reading aloud. Meanwhile, Miguel, in demonstrating a British accent, showed a savvy reading of the dictionary, an unusual way to learn literacy. It is interesting how this student can shift from British English to Standard Philippine English with ease. These examples show how these focal students also exemplify the role of code breakers as they understand the way words work. However, rather than the typical code breaker who decodes words, Miguel and Richard are able to extend their knowledge of phonetics to work on their speech and pronunciation, which they seem to prioritize over the actual process of decoding words.

In his first interview, Richard said that he read the dictionary primarily to be familiar with words so that when he was called to read aloud to the class, he would know how to pronounce words correctly. The following is an excerpt from our second interview during which Richard explained his study habits for English class.

Richard: First, I read the dictionary, because for example when we read a story in class and I didn't really understand it and then there are questions for our assignment. What I do is I go back and read the story and the words I didn't under- 
stand. Then when I read the story again I will know the words and I will be able to answer. I will be able to answer the questions well.

Selena: Okay. What I noticed about you that is different from the others that I have talked to is you're so involved with vocabulary. You seem so focused on vocabulary. Why?

Richard: That's the reason why, so that when I read, I won't be embarrassed. Because when I read, and I read words that I don't know, that's what I focus on.

Richard's statement illustrates that he exhibits word consciousness (Graves \& WattsTaffe, 2008). In other words, he is highly interested in words, and he gains satisfaction from being able to use these words appropriately and pronounce them correctly. Moreover, Richard seemed to have high self-efficacy as a reader. Richard knows he is a good reader, and he believes that he will be able to successfully read a text that is at his level. During the interview he related that if the teacher calls on a student to read, it is because the teacher knows the student is a good reader, and he will be able to read the story clearly. Since Richard was constantly called on to read aloud by the teacher, he knew that the teacher's perception of him as a reader was quite positive. However, he was also concerned about his performance as a reader, and this can be seen from his focus on vocabulary words. Richard articulated why he had such a focus on studying the dictionary and learning vocabulary: "The one I said, the reason I am always reading is because I don't want to get laughed at when I am reading." Even though he knew that he is a good reader, Richard seemed to be anxious about his classmates' perceptions of him while he read aloud. He reiterated that he did not want to embarrass himself in front of his peers when he is reading a story aloud in class. To Richard, reading is synonymous to giving a good performance.

Miguel was also called on frequently to read in class. However, he was not as confident as Richard in reading aloud. Below is an excerpt from his second interview. He noted that his lack of knowledge of vocabulary words affected his oral reading proficiency.

Selena: What about the hard ones? What subject is difficult for you?

Miguel: Vocabulary words.

Selena: Why is vocabulary difficult for you?

Miguel: Because I, I didn't often read the dictionary and I didn't often read our last topic in English so we learn vocabulary words. It's very hard for me.

Selena: How does this affect your studies if you have a hard time with vocabulary words?

Miguel: Because when I speak in English I can't speak correctly because I don't know the meaning of the other English words.

Vocabulary is significant for English Language Learners (ELLs) but more so in relation to their comprehension development. Calderon (2007) asserts that pre-teaching vocabulary is key to reading comprehension development of ELLs. In this instance though, Miguel highlights the importance and relation of vocabulary in giving a good reading performance. Since he realized that his vocabulary skills could be improved, Miguel seemed unsure of his abilities to read aloud despite his being one of the higher performing students in the class. He said that he had difficulties with vocabulary words because he does not read the dictionary often. However, Miguel was the only student who answered in English for both interviews. Despite some lapses in grammar, he was able to communicate with Selena quite well in English, regardless of his anxiety about not being able to perform well as a reader. 
Thus, for the high and average achievers in the class, reading aloud - a performancewas key. Comprehension was not mentioned by the students except in passing by Richard and Miguel, but this was only in relation to their interest in vocabulary words. Furthermore, Tony and Jayca did not mention reading aloud, and perhaps this is because they were not given opportunities to do so in the pilot section.

Through these examples, we can establish that four of the focal students perceived reading as reading aloud in class, a performance in which they could showcase good pronunciation. Although the students mentioned here are ones that were called on frequently to read in class, they still exhibited uneasiness about their abilities to read aloud. There was apprehension about their performance, especially with regard to pronunciation.

We wondered about those students who were not called on to read in class, as in Tony's case. What must be their perceptions of themselves as readers if the collective definition of reading is that of reading aloud correctly? How could they improve as readers in this setting? Perhaps the pronunciation drills that are executed in class are meant to target the best students as models of good reading, but more attention and opportunities must be given to other students to read aloud in class.

When asked to describe the focal students, Mrs. Mendoza described both Miguel and Richard as fast readers with good comprehension skills. She added that Richard is able to "express himself," and by this she meant that he is able to retell the story in his own words. Mrs. Mendoza described Michelle and Angel as good readers with good comprehension skills. However, the teacher says that since she is a girl, Michelle's voice is high pitched, "unlike the boys, whose voices are very loud." From this statement, we can infer two things. First, the teacher includes voice quality when characterizing reading abilities, which provides evidence for our conclusion that reading in this classroom is synonymous to reading aloud, a performance. Second, the teacher seemed to have a preference for boys reading aloud, and this is based on her perception of the boys' voice quality (lower pitch) compared to that of the girls. For the lower achieving focal students, Mrs. Mendoza rated Tony as a seven on a scale of one to 10 as a reader. She elaborated that he is able to read and comprehend. Lastly, the teacher described Jayca as someone who can read but has trouble comprehending, thus indicating that Jayca is able to assume the role of a code breaker but struggles in being a text participant. Mrs. Mendoza explained that Jayca would probably be able to answer the first two questions on a comprehension assessment, usually literal comprehension questions, but she would not be able to retell the story in her own words. Therefore, even in the pilot section, there is, according to the teacher, a varied continuum of reading abilities. However, we still contend that based on the Department of Education's goal of functional literacy, students in this pilot section met that standard, but what counted in this class was how well they performed in reading aloud to the class, a theatre-like performance judged by correct pronunciation and voice pitch.

\section{Discussion and concluding thoughts}

Educational research has become a global enterprise, with researchers recognizing the need to be aware of educational practices in other countries. Burbules (2002) notes that this international context makes possible the sharing of knowledge and experience gained in relation to reform and evaluation in different countries. Our case study offers an example of reading instruction in a Philippine English classroom, a context which has not been given much attention in the field of reading research. It is our hope that through our study, we have shared with literacy researchers and educators another view of reading instruction. We can 
see that in this setting, reading is perceived as an oral performance activity by Filipino students because reading aloud is used frequently to negotiate the lack of resources in Philippine public schools. Comprehension does not matter as much to these students; rather, they are concerned with how they are perceived as oral readers in English, which is their second language. Our case study findings provide a different view of reading, specifically a view of a culture of reading wherein higher status is given to oral performance rather than comprehension or fluency. Our data also show that the predominant emphasis on oral performance satisfies only two roles or family of practices in the "four resources model of reading": code breakers and text users. All of the students in the pilot section were not afforded opportunities by the teacher to fully engage with the four resources, as the class focused mostly on oral recitation as the main indicator for reading well. Students in this class infrequently assumed the role of meaning-makers and text analysts (Luke \& Freebody, 1999; Underwood, Yoo, \& Pearson, 2007). Instead, both students and teacher privileged correct pronunciation and reading correctly aloud - getting the accent right determined who the best students were in the class.

In the literacy field, comprehension is primarily identified as the goal of reading (Duke \& Pearson, 2002; Duke, Pearson, Strachan, \& Billman, 2011). While we agree that comprehension is of utmost importance, we argue that in this classroom context, focusing on students' fluency did not limit students' development as readers, particularly for those who were asked to read aloud. What we do feel strongly about is the importance of providing all students opportunities to assume the role of readers in this classroom by giving all students a chance to read aloud in class. However, we noticed that, sadly, this was not the case. There were students such as Richard and Miguel, who were proficient and motivated readers in English, and who were regular "performers" in the classroom. We worry, however, about students such as Tony and Jayca, and what their perceptions might be of themselves as readers since they were not given opportunities to practice reading aloud.

Thus, we hope that the findings of this study will provide global educators with a better understanding of English learners' previous literacy experiences (e.g., Smith, Jimenez, \& Martinez-Leon, 2003) as well as a deeper appreciation of cultural differences in learning and teaching (Luke \& Carpenter, 2003). We hope that this case study offers researchers and educators the opportunity to see that literacy instruction differs from context to context. What might be emphasized in one country may be placed on the back-burner in another. Consequently, it is important for teachers of immigrant students to engage in conversations with these students about their reading experiences in their native countries to better understand these students' conceptions of reading. In addition, teachers of English learners need to be transparent with the goals of reading instruction in students' current classroom contexts.

The findings of this study also point to the importance of teachers examining their own perceptions about reading and reading instruction (Edwards, Martin, Protacio, \& Razali, 2010). We suggest that this is noteworthy because students' understandings and perceptions of reading might differ from teachers' own perceptions of what counts as reading. This study, thus, contributes another cultural notion of what literacy is (Jiménez, Smith, \& Martínez-León, 2003).

In summary, our research provides a detailed description of a classroom that might look very different from those seen in other countries, whether it be because of the lack of resources like textbooks, different curriculum foci, or lack of attention to national exams. Further research could be conducted in non-pilot and non high-achieving English classrooms in the Philippines to better understand how teachers and students negotiate global and local expectations for success in relation to reading, in English, Taglish, and Filipino. 


\section{References}

Bogdan, R. C., \& Biklen, S. (2003). Qualitative research for education: An introduction to theories and methods (4th ed.). New York: Pearson Education Group.

Burbules, N. (2002). The global context of educational research. In L. Bresler \& A. Ardichvili (eds.), Research in international research: Experience, theory, and practice. New York: Peter Lang Publishing.

Calderon, M. (2007). Teaching reading to English language learners, grades 6-12: A framework for improving achievement in the content areas. Thousand Oaks, CA: Corwin Press.

Duke, N. K., \& Pearson, P. D. (2002). Effective practices for developing reading comprehension. In S. J. Samuels \& A. E. Farstrup (eds.), What research has to say about reading instruction (3rd ed., pp. 205-242). Newark, DE: International Reading Association.

Duke, N. K., Pearson, P. D., Strachan, S. L., \& Billman, A. K. (2011). Essential elements of fostering and teaching reading comprehension. In S. J. Samuels \& A. E. Farstrup (eds.), What research has to say about reading instruction (4th ed., pp. 51-93). Newark, DE: International Reading Association.

Edwards, P. A., Martin, N. M., Protacio, M. S., \& Razali, A. B. M. (2010, December). The role of texts/ readings in shaping and changing in-service teachers' conceptions of literacy. Paper presented at the Literacy Research Association Conference, Fort Worth, TX.

Emerson, R., Fretz, R., \& Shaw, L. (1995). Writing ethnographic fieldnotes. Chicago: University of Chicago Press.

Freebody, P., \& Luke, A. (1990). Literacies programmes: Debates and demands in cultural context. Prospect: A Journal of Australian TESOL, 5(3), 7-16.

Graves, M. F., \& Watts-Taffe, S. (2008). For the love of words: Fostering word consciousness in young readers. The Reading Teacher, 62(3), 185-193.

Jiménez, R. T., Smith, P. H., \& Martínez-León, N. (2003). Freedom and form: The language and literacy practices of two Mexican schools. Reading Research Quarterly, 38(4), 488-508.

Kim, H., \& Krashen, S. (1997). Why don't language acquirers take advantage of the power of reading? TESOL Journal, 6(3), 26-29.

Labaree, D. (1997). Public goods, private goods: The American struggle over educational goals. American Educational Research Journal, 34, 39-81.

Lu, D. (2002). Phonetic symbols: A necessary stepping stone for ESL learners. English Teaching Forum, 40(4), 36-39.

Luke, A., \& Carpenter, M. (2003). Literacy education for a new ethics of global community. Language Arts, 81, 20-22.

Luke, A., \& Freebody, P. (1999). Further Notes on the Four Resources Model. Retrieved from http:// readingonline.org/research/lukefreebody.html

Maminta, R. (1982). Issues and trends in teaching reading in English in the Philippines. Philippine Journal of Language Teaching, 10(3), 20-29.

Miles, M., \& Huberman, A. (1994). Qualitative data analysis (2nd ed.). New York: Sage.

Smith, P., Jimenez, R., \& Martinez-Leon, N. (2003). Other countries' literacies: What U.S. educators can learn from Mexican schools. The Reading Teacher, 56(8), 772-781.

Spradley, J. (1979). The ethnographic interview. New York: Holt, Rinehart, and Winston.

Strauss, A., \& Corbin, J. (1990). Basics of qualitative research: Grounded theory procedures and techniques. London: Sage.

Street, B. V. (2005). Recent applications for new literacy studies in educational contexts. Research in the Teaching of English, 39(4), 417-423.

Underwood, T., Yoo, M. S., \& Pearson, P. D. (2007). Understanding reading comprehension in secondary schools through the lens of the four resources model. In L. S. Rush, A. J. Eakle \& A. Berger (eds.), Secondary school literacy: What research reveals about classroom practice (pp. 90-116). Urbana, IL: NCTE.

Varenne, H., \& McDermott, R. (1998). Successful failure: The school America builds. Colorado: Westview Press. 